\title{
Desain Sistem Informasi Manajemen Rantai Pasok pada PT “ABCD” Bandung Jawa Barat Indonesia
}

\author{
Maun Jamaludin \\ Program Studi Ilmu Administrasi Bisnis, Universitas Pasundan, Bandung, Indonesia \\ *Email: maun.jamaludin@unpas.ac.id
}

\begin{abstract}
The objectives of this research are: (1) To simplify business processes so that supply chain management starts from raw materials to finished materials and distributes these products to end consumers effectively and efficiently; (2) Build a web-based supply chain management application system to make it easier for companies in their business processes. This research method uses qualitative methods. The final results of this study: (a) Application of supply chain management information system designed for PT. ABCD can reduce supply chain uncertainty in companies. Because the implementation of the system can help the company in controlling the procurement of raw materials that must always be available in accordance with the company's needs; (b) The supply chain management information system application that is designed can describe the correlation between suppliers and companies, companies and users who can facilitate ordering goods from suppliers to companies and vice versa, so that the delivery of ordered goods is in accordance with the order and arrives at the company on time and in the right amount; (c). Provide opportunities for suppliers to participate in the implementation of the system to provide online price quotes.
\end{abstract}

Abstraksi: Tujuan Penelitian ini adalah untuk: (1) Mempermudah dalam proses bisnis sehingga dalam pengelolaan rantai pasok mulai dari bahan mentah sampai bahan jadi dan mendistribusikan produk tersebut kepada konsumen akhir dapat berjalan secara efektif dan efisien; (2) Membangun suatu sistem aplikasi manajemen rantai pasok yang berbasis website sehingga lebih memudahkan perusahaan dalam proses bisnisnya. Metode penelitian ini menggunakan metode kualitatif. Hasil akhir penelitian ini antara lain (a) Penerapan sistem informasi manajemen rantai pasok yang dirancang untuk PT. ABCD bisa mengurangi ketidakpastian rantai pasok pada perusahaan. Sebab, penerapan sistem tersebut bisa membantu perusahaan dalam pengadaan dan mengendalikan bahan baku yang mesti selalu tersedia sesuai dengan keinginan perusahaan; (b) Aplikasi sistem informasi manajemen rantai pasok yang dirancang tersebut dapat menggambarkan korelasi pemasok dengan perusahaan, perusahaan dengan pemakai yang bisa mempermudah pemesanan barang dari pemasok ke perusahaan maupun sebaliknya sehingga pengiriman barang yang dipesan sesuai dengan pesanan dan sampai ke perusahaan tepat waktu dan tepat jumlah; (c) Memberi peluang kepada pemasok agar ikut serta ke dalam penerapan sistem tersebut untuk memberikan penawaran harga secara online.

Kata Kunci: Sistem informasi; Manajemen Rantai Pasok; Supplier

\section{Pendahuluan}

Pada zaman modern ini, suatu perusahaan besar (industri) tidak lepas dari suatu teknologi dalam penerapannya sehingga dituntut untuk menghasilkan sebuah produk yang berkualitas dengan harga murah dengan menggunakan teknologi informasi yang modern pula. Salah satu syarat perusahaan besar (industri) adalah perusahaan yang memiliki kemampuan menghubungkan lingkungan dalam dan lingkunggan luar perusahaan, seperti halnya rantai pasok distribusi yang berada pada ruang lingkup ekternal perusahaan. Menurut Kowo \& Popoola (2018), lingkungan internal perusahaan merupakan aset perusahaan yang paling mempengaruhi kekuatan dan kelemahan perusahaan. Aset perusahaan yang paling penting adalah sumber daya manusia.. Sumber daya perusahaan yang lainnya diantaranya adalah sistem dan proses perusahaan, strategi perusahaan, struktur budaya, bagian pembelian bahan baku, bagian produksi dan operasi, bagian keuangan, bagian riset dan pengembangan, bagian marketing, bagian sistem pengendalian, dan sistem informasi. Sumber daya fisik diantaranya pabrik dan peralatannya, tata letak perusahaan, akses masuk bahan baku, saluran distribusi dan teknologi yang digunakan. Apabila perusahaan ingin memaksimalkan sumber daya tersebut, maka ketiga sumber daya tersebut dapat meningkatkan kinerja 
perusahaan dalam meraih keunggulan yang berkelanjutan.

Lingkungan dalam perusahaan perlu dikaji agar dapat mengidentifikasi kekuatan dan kelemahan pada perusahaan (Kuznetsova et al., 2017). Struktur adalah salah satu organ perusahaan yang diorganisasikan yang berhubungan dengan komunikasi, tanggung jawab, dan wewenang serta jaringan kerja (Gholam Ali Ahmadya, Maryam Mehrpour, 2016). Struktur disebut jaringan perintah yang dapat diilustrasikan dalam bentuk grafik dengan menggunakan bagan organisasi (Susanthi, 2017). Budaya adalah bentuk keyakinan seseorang, harapan, dan nilai-nilai budaya yang diberikan kepada anggota organisasi (Nafchi \& Mohelská, 2020).

Lingkungan luar perusahaan merupakan suatu lingkungan yang berada di luar organisasi yang perlu dikaji juga dalam menentukan adanya peluang dan tantangan yang dihadapi oleh suatu perusahaan (Kowo \& Popoola, 2018). Ada dua paradigma dalam mengonseptualisasilkan lingkungan luar perusahaan (Susanthi, 2017). Pertama, paradigma yang melihat bahwa lingkungan luar perusahaan merupakan sarana yang menyediakan sumber daya. Kedua, paradigma yang memiliki pandangan bahwa lingkungan luar perusahaan merupakan sumber informasi juga. Paradigma pertama bersumber kepada asumsi bahwa lingkungan luar perusahaan merupakan sarana untuk ketersediaan sumber daya yang paling penting untuk berlangsungnya hidup suatu perusahaan. Paradigma ini memiliki arti yang potensial di luar perusahaan yang akan mengancam sumber daya internal perusahaan yang dimiliki oleh perusahaan. Suatu kebijakan pemerintah seperti adanya perubahan regulasi berpeluang merusak sumber daya internal perusahaan (Susanthi, 2017).

Paradigma kedua memiliki informasi yang tidak pasti mengenai lingkungan luar perusahaan. Ketidakpastian lingkungan luar perusahaan bersumber dari kondisi lingkungan luar perusahaan yang tidak dapat diprediksi pola perubahannya. Hal tersebut berhubungan dengan skill dari setiap anggota organisasi dalam proses pengambilan keputusan (Susanthi, 2017).
Untuk dapat meningkatkan proses bisnis tersebut dibutuhkan suatu manajemen rantai pasok yang bisa berjalan dengan baik karena perusahaan harus mampu berkomunikasi dengan baik dengan para mitra bisnisnya (Sadraoui \& Mchirgui, 2014). Selain dapat meningkatkan efisiensi dan kualitas produk, suatu perusahaan harus dapat meningkatkan keunggulan bersaing (Ranjith, 2016). Pada proses pengadaan bahan baku dari pemasok ke pabrik merupakan sesuatu yang sangat penting karena keberhasilan perusahaan dalam proses bisnisnya diperlukan suatu metode yang tepat untuk mempermudah proses tersebut (Ranjith, 2016). Menurut (Banerjee, 2017), Manajemen rantai pasok merupakan interaksi antar perusahaan yang bekerja sama untuk membuat dan menghasilkan produk ke pengguna akhir. Sementara itu, menurut (Jamaludin et al., 2021), manajemen rantai pasok merupakan kombinasi atau gabungan dari beberapa pemasok untuk menjalankan proses bisnisnya agar tersedia produk, jasa, dan informasi agar tercipta added value bagi pelanggan dan pihak-pihak yang berkepentingan. Faktor yang sangat berpengaruh untuk keberhasilan implementasi manajemen rantai pasok adalah teknologi informasi. Dengan teknologi informasi, bagian-bagian yang terlibat dalam jaringan Supply Chain Management (SCM) dapat membagikan informasi dengan sangat mudah, cepat, dan akurat.

P.T. "ABCD" adalah suatu industri tekstil terbesar di Bandung. Proses pengadaan bahan bakunya dimulai dari pemasok (supplier) kemudian sampai ke gudang harus bisa memberikan informasi yang cepat, tepat serta akurat, yang pada akhirnya produk tersebut tergantung kepada persediaan bahan baku yang harus selalu tersedia pada saat dibutuhkan. Kemudian perusahaan juga diharuskan dapat bekerjasama atau melakukan hubungan yang saling menguntungkan antarpemasok untuk menjamin ketersediaan bahan baku agar dapat berjalan dengan lancar. Selanjutnya pada bagian pembelanjaan atau pengadaan, bagian perencanaan dan pengendalian produksi, bagian akuntasi, bagian pergudangan serta pemasok merupakan bagian yang paling penting pada setiap kali dilakukannya pembelian bahan baku. 
Permasalahan dalam pembelian bahan baku yang sering kali terjadi pada saat ini adalah terlambatnya pada proses pengadaan sehingga berdampak terhadap keberlanjutan pada proses produksi. Proses pengadaan tersebut disebabkan oleh keterlambatan pemasok dalam menjawab penawaran harga yang hanya melalui surat elektronik (email) dan birokrasi yang terlalu panjang yang memakan waktu dari satu bagian ke bagian lainnya. Misalnya proses persetujuan dokumen permintaan barang yang memakan waktu lama karena pegawai yang bertugas saat itu jarang ada di tempat, tidak hadir, tugas luar kota, atau cuti sehingga harus menunggu tanda tangan atau persetujuan dari pegawai atau pejabat tersebut.

Berdasarkan persoalan tersebut, maka perlu adanya suatu desain sistem informasi manajemen rantai pasok yang terintegrasi di semua divisi perusahaan sehingga proses pengadaan bahan baku tidak lagi terlambat. Alhasil, proses produksi berjalan dengan lancar, hubungan antarpemasok atau perusahaan juga menjadi lancar karena telah menggunakan sistem yang terintegrasi, prosedur yang tidak lagi berbelit-belit karena sudah dibuatkan standar operasional prosedur (SOP) yang baku.

Dengan diterapkannya sistem informasi manajemen rantai pasok tersebut diharapkan dapat membantu mengurangi permasalahan di internal perusahaan yang mengakibatkan inefisiensi dan inefektifitas operasioanal perusahaan. Sebab, sistem tersebut sudah secara lengkap meyediakan informasi pada setiap divisi perusahaan sehingga dapat mengurangi kesimpangsiuran komunikasi dalam kegiatan rantai pasok serta dapat dijadikan acuan bagi para pengambil keputusan dengan cepat, tepat, dan akurat. Dengan diterapkannya sistem informasi manajemen rantai pasok tersebut diharapkan dapat menjalin hubungan yang saling menguntungkan dengan eksternal perusahaan, seperti menjalin hubungan yang harmonis dengan para pemasok (supplier) sehingga perusahan dapat tumbuh dan berkembang.

\section{Kajian Teori}

\section{Konsep Sistem dan Informasi}

Sistem adalah gabungan dari unsur-unsur yang saling berinteraksi satu dengan lainnya dan saling berhubungani serta saling bergantung satu dengan lainnya seingga membentuk tujuan dari sistem itu sendiri (Boell \& Cecez-Kecmanovic, 2015). Sementara itu, menurut (Meijer, 2013), sistem adalah suatu kelompok dari unsur-unsur yang tergabung dengan maksud dan tujuan untuk mencapai sasaran pengguna. Informasi merupakan data yang sudah diolah menjadi model yang lebih bermanfaat sesama pemakainya serta untuk para pengambil keputusan pada saat kini dan saat yang akan datang (Meijer, 2013). Sistem informasi merupakan suatu alat untuk menyampaikan dan menyajikan informasi yang berguna bagi para pemakainya (Meijer, 2013).

\section{Konsep Manajemen Rantai Pasok}

Menurut (Rachbini, 2016), manajemen rantai pasok merupakan kumpulan aktivitas (set of activity) yang saling berhubungan satu dengan lainnya untuk menggabungkan bagian pemasok, bagian produksi, bagian gudang, bagian transportasi, penjual, dan pemakai dengan efektif dan efisien sehingga produk tersebut dapat didistribusikannya pada waktu, jumlah, dan lokasi yang tepat untuk meminimumkan biaya operasional perusahaan agar kebutuhan konsumen terpenuhi secara optimal.

Manajemen rantai pasokan merupakan suatu pendekatan yang diterapkan pada perusahaan agar tercapai efisiensi integrasi supplier, proses produksi, pergudangan, dan penyimpanan barang agar barang dapat diproduksi dan didistribusikan pada lokasi yang tepat dengan jumlah yang tepat, pada saat yang tepat untuk meminimasi biaya operasional perusahaan dan dapat memberikan pelayanan yang optimal bagi pelanggan (Shu-SanGan, 2017). Rantai pasok meliputi keseluruhan hubungan antara pemasok, perusahaan yang berbasis pada proses produksi, para distributor, dan pemakai akhir. Hal ini berkaitan dengan transportasi, informasi penjadwalan produksi, kredit maupun cash, serta pengiriman barang-barang 
dengan pihak-pihak yang terkait (Magar \& Khandare, 2016).

Proses strategi manajemen rantai pasok menurut Magar \& Khandare (2016) meliputi tiga tujuan. Tujuan yang pertama adalah cost reduction dimana strategi manajemen rantai pasok yang dilakukan perusahaan harus dapat memperkecil biaya logistik, misalnya harus dapat memilih peralatan transportasi yang tepat, tata kelola penggudangan yang maksimal, dan pelayanan yang dapat memperkecil biaya. Tujuan kedua adalah untuk pengurangan modal atau biaya operasioanl perusahaan serta ditujukan untuk memperkecil tingkat pemodalan dan strategi distribusi logistik. Strategi ini bisa menimbulkan variable cost yang lebih tinggi dari strategi yang dibutuhkan pada tingkat investasi yang lebih tinggi dan pada saat pengembalian modal diharapkan dapat meningkat. Tujuan yang ketiga dari penerapan strategi manajemen rantai pasok adalah dapat memperbaiki pelayanan secara optimal kepada konsumen secara terus menerus (Agus, 2016).

Menurut Jamaludin et al. (2021), manajemen rantai pasok merupakan sebuah rantai pasok terdiri dari pelibatan setiap mata rantai persediaan, baik itu secara langsung maupun tidak langsung untuk memenuhi permintaan pelanggan. Manajemen rantai pasok merupakan koordinasi dari semua kegiatan rantai pada suatu organisasi dari pemasok (supplier) dan partner ke konsumennya. Sementara itu, menurut Agus (2016), manajemen rantai pasok adalah dasar dalam proses produksi dimana produk dibuat dan didistribusikan kepada pengguna akhir.

Menurut Rahmasari (2011), manajemen rantai pasok terdiri dari tiga komponen, di antaranya (1) Manajemen rantai pasok hulu adalah suatu proses dimana perusahaan dalam mendapatkan pemasok selalu melibatkan pihak dari luar perusahaan untuk memperoleh bahan baku; (2) Manajemen rantai pasok adalah sebuah proses dimana terjadi suatu perubahan dalam pengadaan bahan baku menjadi barang jadi; (3) Manajemen rantai pasok hilir merupakan suatu proses pendistribusian bahan baku oleh perusahaan ke konsumen akhir yang dilakukan oleh pihak luar distributor.

\section{Keuntungan Penerapan Manajemen Rantai} Pasok

Menurut Koech \& Ronoh (2016), keuntungan menerapkan manajemen rantai pasok ialah: (1) Dapat mengurangi biaya persediaan barang. Persediaan adalah bagian yang sangat besar dari harta perusahaan yang berkisar antara 30\% - 40\% dari aset perusaahaan. Oleh sebab itu, yang harus diperhatikan adalah bagaimana cara untuk memperkecil penumpukan bahan baku dan barang jadi di gudang agar biaya penyimpanan barang digudang bisa ditekan sekecil mungkin; (2) Dapat mempertahankan kelangsungan hidup dalam proses persediaan barang. Kelancaran dalam ketersediaan produk yang harus dijaga adalah dari mana barang itu berasal, siapa pemasoknya, siapa distributornya, siapa pengecernya sampai ke konsumen akhir; (3) Dapat mempertahankan kualitas barang. Kualitas barang ditentukan oleh bukan saja dalam proses produksinya, tetapi ditentukan juga oleh kualitas bahan bakunya serta kualitas pengirimannya yang tepat waktu; (4) Dapat mengurangi jumlah pemasok. Mengurangi jumah pemasok dengan tujuan untuk meminimalisasi tingkat ketidakseragaman barang, mengurangi biaya negosiasi, dan pelacakan barang; (5) Dapat mengembangkan kemitraan pemasok. Dengan diadakannya kerja sama antarmitra pemasok dan dikembangkannya kerja sama yang strategis dapat menjamin kelancaran aktivitas barang dalam rantai pasok.

\section{Metode}

Metode penelitian ini menggunakan metode kualitatif, yaitu menerangkan permasalahan penelitian ini secara utuh dan objektif sesuai dengan fakta dan data yang sebenarnya. Selain itu, dengan metode ini lebih memiliki kedalaman dan ketajaman analisis dalam mengungkap fakta, data, dan makna serta menyikap masalah yang tersembunyi tentang rancangan atau desain sistem informasi manajemen rantai pasokan pada P.T. "ABCD" sehingga tujuan penelitian ini akan dapat dicapai.

\section{Fokus Penelitian}

Fokus penelitian ini mendesain sistem informasi manajemen rantai pasok pada P.T. “ABCD” Bandung. 


\section{Jenis Data}

Jenis data dalam penelitian ini menggunakan data primer dan data sekunder. Data pimer merupakan data yang didapat langsung dari lapangan melalui wawancara secara mendalam melalui sumber data (para informan) penelitian dan pengamatan langsung yang dilakukan oleh peneliti. Sementara itu, data sekunder merupakan data yang diperoleh dari pihak kedua seperti (a). studi kepustakaan sebagai sumber data dalam bentuk buku-buku, laporan penelitian, jurnaljurnal ilmiah baik yang bereputasi nasional maupun yang bereputasi internasional yang berhubungan dengan kosep-konsep, teoriteori atau data tentang desain sistem informasi manajemen rantai pasok. (b) berupa dokumendokumen yang merupakan sumber data bagi peneliti untuk perancangan sistem informasi manajemen rantai pasok seperti diagram alur (flowchart) rantai pasok P.T. "ABCD", kinerja rantai pasok P.T. ABCD dan data kegiatan rantai pasok P.T. ABCD tahun sebelumya yakni tahun 2020 .

\section{Teknik Pengumpulan Data}

Teknik pengumpulan data dalam riset ini adalah menggunakan metode explanatory survey adalah menghimpun atau mengumpulkan informasi secara langsung dari lapangan untuk mendapatkan data yang alamiah (apa adanya). Penelitian ini menggunakan metode-metode diantaranya: (a) wawancara dengan para informan kunci (key informan) yaitu direktur utama, para direktur terkait yang berada di P.T. ABCD untuk mengetahui secara garis besar kegiatan per divisi rantai pasok, menilai kinerja sistem informasi manajemen rantai pasok yang sudah ada serta ingin mengetahui tujuan apa yang ingin dicapai dengan adanya sistem informasi manajemen rantai pasok; (b). dokumentasi merupakan informasi penting yang berasal dari perusahaan. Dokumentasi yang dibutuhkan dari perusahaan tersebut diantaranya kegiatan nyata rantai pasok pada setiap divisi pada tahun 2020. Untuk selanjutnya dapat diaplikasikan untuk membuat usulan dalam pengambilan keputusan.

\section{Informan Kunci (Key Informan)}

Informan inti atau kunci (key informan) pada riset ini adalah direktur utama P.T. $\mathrm{ABCD}$, direktur produksi, direktur pemasaran, para sales, pegawai, dan konsumen P.T. $\mathrm{ABCD}$ Bandung yang terlibat langsung dalam penentuan desain sistem informasi manajemen rantai pasok pada P.T. ABCD Bandung.

\section{Teknik Analisis Data}

Teknik analisis data pada riset ini adalah teknik analisis deskriptif kualitatif adalah untuk memperoleh deskripsi tentang sistem informasi manajemen rantai pasok di P.T. ABCD. Dalam menganalisis data ini digunakan perbandingan antara sistem informasi manajemen rantai pasok saat ini (sistem yang sedang berjalan) dengan desain sistem informasi manajemen rantai pasok yang akan didesain atau direncanakan.

\section{Hasil dan Pembahasan}

\section{Analisis Sistem Saat Ini}

Analisis sistem pada saat ini dibagi menjadi dua yaitu order barang ke pemasok (supplier) dan penerimaan barang oleh pemasok (supplier). Pada proses order barang ini melibatkan tiga divisi yaitu (a) divisi pemasaran yang bertugas mengajukan rencana kebutuhan bahan baku; (b) divisi perencanaan dan pengandlian produksi yang bertugas menyediakan informasi posisi stok barang yang harus dipesan kepada bagian pembelanjaan barang (purchasing order); (c) divisi pembelanjaan bertugas mengajukan pesanan barang dan hasil dari pesanan barang tersebut dicatat oleh divisi akuntansi; (d) divisi akuntansi bertugas menyetujui atau tidak. Jika disetujui dicatat pesanan barang tersebut. Penerimaan barang dari pemasok (supplier) dilakukan pada bagian gudang. Selanjutnya pada bagian gudang dilakukan verifikasi atau pemeriksaan barang yang datang dan harus sesuai dengan barang yang dipesan (purchase order), misalnya surat jalan harus ada dan lengkap, faktur-faktur pembelanjaan harus lengkap dan daftar rincian barang yang dipesan harus detail. Dokumentasi atau faktur-faktur atau tanda bukti yang disertakan dan dilampirkan oleh divisi gudang merupakan tanda bukti penerimaan barang yang wajib disahkan oleh: 
(a) Kepala seksi benang; (b) Kepala divisi Benang; (c) Kepala divisi bahan baku; dan (d) pejabat perusahaan lainnya.

Persoalan yang timbul akibat terlambatnya proses pemesanan barang disebabkan oleh tiga faktor sebagai berikut: (1) Kurang tanggapnya pemasok dalam proses pemesanan lewat surat elektronik terasa lambat karena proses penawaran harga terjadi di bagian pemesanan barang; (2) Karyawan wajib memberikan bukti persetujuan permintaan barang, sering tidak masuk kerja alias bolos tanpa ada pemberitahuan sebelummya dengan alasan yang tidak masuk akal dan lain-lain; (3) Alur permintaan barang yang terlalu panjang dan berbelit-belit karena perpindahan dokumen dari pegawai yang satu ke pegawai yang lainnya. Atas dasar tersebut, perlu dirancang atau didesain sistem informasi manajemen rantai pasokan yang terintegrasi dari awal sampai ahir.

Desain (Rancangan) Sistem Informasi Manajemen Rantai Pasok yang Diusulkan

Desain Sistem Informasi manajemen rantai pasokan yang diusulkan merupakan pengembangan dari sistem lama ke sistem baru, dimana permasalahan yang terjadi pada

sistem lama diharapkan dan harus dapat diselesaikan dengan sistem yang baru.

Pada desain sistem ini dibuatkan suatu model sistem yang dapat menggambarkan bentuk bagan antara lain paket diagram (diagram of package), use case, dan diagram aktivitas (diagram of activity). Diagram tersebut diuraikan pada Gambar 1.
Diagram paket adalah salah satu jenis UML (Unified Modeling Language) yang dipergunakan untuk mengelompokkan elemen-elemen model dari use case dan diagram kelas.

Menurut Sonata (2019), UML merupakan tools atau alat atau model untuk mendesain pengembangan perangkat lunak yang berbasis orientasi objek. UML memberikan sebuah standar penulisan yang berjenis kerangka kerja yang terperinci yang terdiri dari konsep bisnis, penulisan statementstatement dalam bahasa pemroggraman khusus yang berbsis database dengan komponen-komponen sistem yang diperlukan dalam sistem perangkat lunak. Diagram paket (package diagram) akan memisahkan output atau tampilan layar dan akses data kepada paket diagram yang terpisah. Dengan diagram paket ini dapat dengan mudah dibuat dan dikumpulkan atribut-atribut yang sejenis. Setiap paket diagram akan diberi nama sesuai dengan isinya sehingga package diagram tersebut dapat dipakai pada beberapa keperluan dan kebutuhan yang akan datang. Kegunaan paket diagram yang paling umum adalah digunakan untuk mengelompokkan kelas-kelas. Pada penelitiaan ini diagram paket yang didesain terdiri dari diatas 8 paket diagram: (1) paket file induk (master file); (2) paket file transaksi; (3) paket file pendaftaran; (4) paket file pembelian (purchasing); (5) paket file pemasok (supplier file); (6) paket file gudang; (7) paket file raw material; (8). paket file PPC; dan (9) paket file laporan.

\section{Package Diagram (Diagram Paket)}

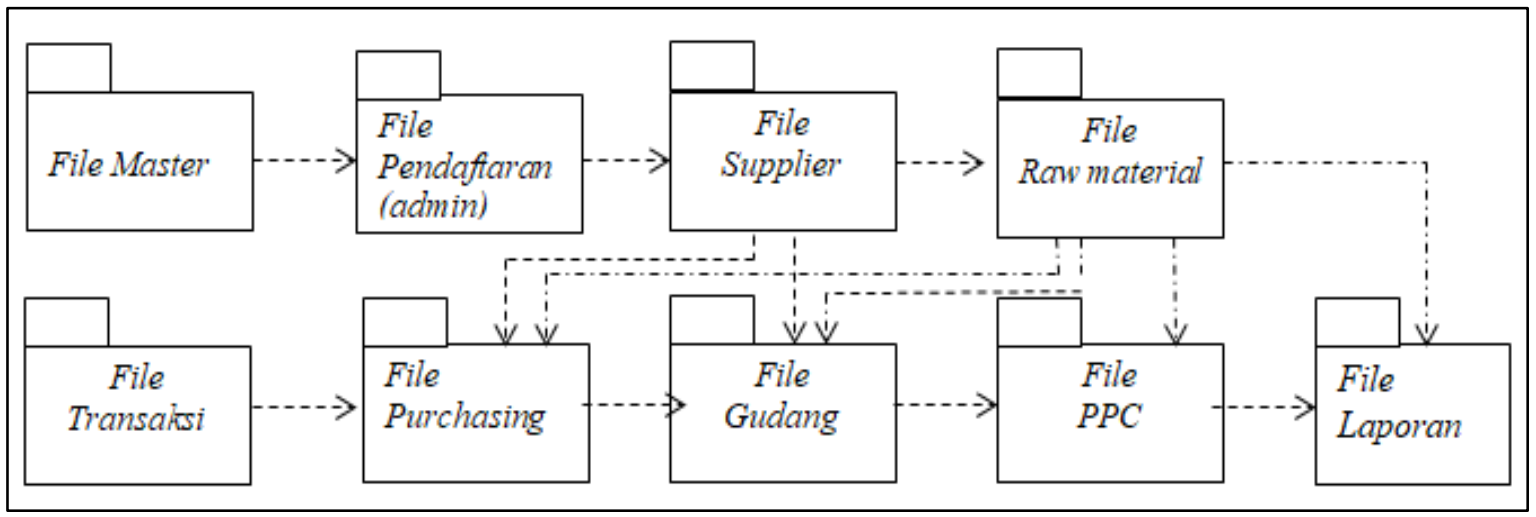

Gambar 1. Package Diagram 
Paket file induk (master file) adalah dokumen yang paling penting pada suatu sistem. File induk adalah file yang dipergunakan untuk menyelesaikan tugas pokok tertentu dan harus selalu terpelihara dengan baik dan secara teratur. File induk (file master) dipergunakan untuk menyimpan data dari sistem informasi tertentu secara lengkap dan selalu terpelihara secara sistematis. File master ini adalah file utama dari pada file-file pendukung lainnya. File ini sangat diperlukan untuk memperlancar proses jalannya operasi sistem yang selalu diperbarui secara sistematis. File master (fie induk) berisi file data admin, file data supplier dan file data bahan baku. File transaksi merupakan file yang berisikan suatu informasi yang dipergunakan untuk mengupdate file induk (file master) karena dengan keberadannya file transaksi ini, file induk dapat berubah sesuai dengan informasi yang berada pada file transaksi tersebut. File transaksi dipergunakan untuk meng-update file induk dengan informasi yang terbaru atau selalu uptodate. File transaksi berisikan informasi yang digunakan untuk selalu mengupdate file induk. File transaksi dalam sistem informasi ini terdiri dari file purchasing, file gudang, file PPC dan file laporan. Paket file pendaftaran digunakan untuk melakukan pendaftaran pengguna sistem. Paket file purchasing digunakan mengelola pembelian suatu barang. Paket file supplier digunakan untuk mengelolaan supply barang oleh supplier. Paket file gudang digunakan untuk pengelolaan barang yang disuppy oleh suppier. Paket file raw material untuk pengeloaan stok barang di gudang. Paket file PPC digunakan untuk merencanakan dan pengendalian produksi. Paket laporan yang beriskan data untuk proses laporan atau keperluan pengguna

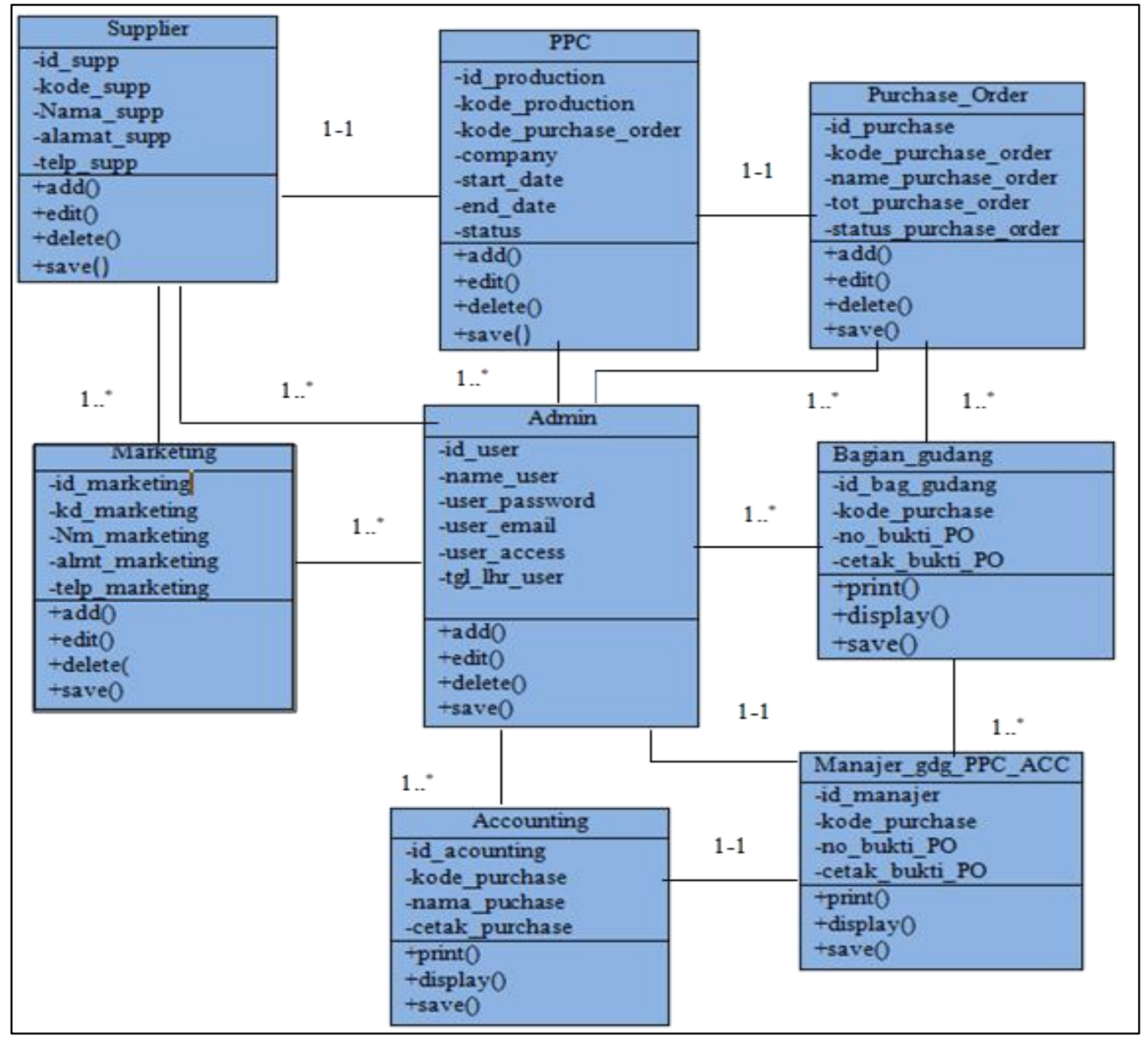

Gambar 2. Diagram Class 
lainnya, file ini hanya bisa dicetak atau diprint-out pada kertas printer atau hanya ditampilkan pada layar monitor. Untuk lebih jelasnya pada sistem ini dapat dilihat pada Gambar 2.

\section{Class Diagram}

Diagram kelas adalah korelasi antar kelas dan penjelasan yang dilakukan secara terperinci pada setiap kelas pada suatu model desain dari suatu sistem. Diagram kelas merupakan alur sistem jalannya pangkalan data (database) pada suatu sistem. Diagram kelas akan menguraikan struktur sistem dari sudut konsep setiap kelas yang dibuat untuk membentuk suatu sistem. Diagram kelas akan menguraikan struktur sistem dari sudut pendefinisian setiap kelas yang dibuat dalam membentuk suatu sistem. Setiap kelas memiliki atribut, metode atau operasi.

Adapun gambaran mengenai diagram kelas pada perancangan sistem database yang akan dibangun ditunjukkan pada Gambar 2.

Pada sistem informasi rantai pasok yang akan dibangun terdiri dari 8 kelas diagram yang meliputi diagram kelas supplier. Diagram kelas supplier terdiri dari atribut id_supp (identitas supplier) kode_spp (kode supplier), nama_supp (nama supplier) dan telp_supp (telpon supplier). Diagram kelas supplier terdiri dari metode atau operasi add (tambah data), edit (ubah data), detete (hapus data) dan save (simpan data). Diagram kelas PPC (Planning Production Control) terdiri dari atribut id_production (identitas produksi), kode_production (kode produksi), kode_purchase_order (kode order pembelian/pembelanjaan), company (nama_perusahaan), start_date (tanggal_mulai), end_date (tanggal berakhir) dan status (status). Diagram kelas PPC terdiri dari metode atau operasi add (tambah data), edit (ubah data), delete (hapus data) dan save (simpan data). Diagram kelas purchase Order terdiri dari attribut id_purchase (identitas pembelian), kode_purchase order (kode order pembelian), nama_purchase_order (nama order pembelian), tot_purchase_order (total order pembelian), status_purchase_order (status order pembelian). Diagram kelas purchase Order terdiri dari metode atau operasi add (tambah data), edit (ubah data), delete (hapus data) dan save (simpan data).
Diagram Marketing terdiri dari atribut id_marketing (identitas marketing), kd_marketing (kode marketing), nm_marketing (nama marketing), almt_marketing (alamat marketing) dan telp_marketing (telpon marketing). Diagram Marketing terdiri dari metode atau operasi add (tambah data), edit (ubah data), delete (hapus data) dan save (simpan data). Diagram kelas Admin terdiri dari atribut id_user (identitas pengguna), nama_user (nama pengguna), user_password (password pengguna), user_acceses (hak akses pengguna) dan tgl_lhr_user (tanggal lahir pengguna). Diagram kelas Admin terdiri dari metode atau operasi add (tambah data), edit (ubah data), delete (hapus data) dan save (simpan data). Diagram kelas bagian gudang terdiri attribut id_bag_gudang (identitas bagian gudang), kode_purchase (kode pembelian), no_bukti_po (nomor bukti pembelian) dan cetak_bukti_po (cetak bukti order pembelian) Diagram kelas bagian gudang terdiri metode atau operasi print (cetak data, display (tampilkan di layar monitor), dan save (rekam data). Diagram kelas accounting terdiri dari attribut id_acounting (identitas akunting), kode_purchase (kode pembelanjaan), nama_purchase (nama orang yang melakukan pembelian), cetak_purchase (cetak bukti pembelian). Diagram kelas accounting terdiri dari metode atau operasi print (cetak data, display (tampilkan di layar monitor), dan save (rekam data). Diagram kelas manager gudang dan manajer PPC terdiri dari attribut id_manajer (identitas manajer), kode_purchase (kode pembelian), no_bukti_po (nomor bukti order pembelian) dan cetak_bukti_po (nomor bukti cetak order pembelian). Diagram kelas manager gudang dan manajer PPC terdiri dari metode atau order print (cetak data, display (tampilkan di layar monitor), dan save (rekam data).

\section{Use Case Diagram}

Diagram use case adalah satu model yang menjelaskan perilaku sistem yang akan didesain. Diagram use case juga mengabstraksikan korelasi satu atau lebih aktor sistem yang akan didesain. Diagram use case dipergunakan untuk memahami aktivitas suatu sistem yang terlibat dalam penggunaan fungsi-fungsi tersebut. Gambar 3 menunjukkan diagram use case desain sistem 
informasi manajemen rantai pasok (SIMSC) yang diusulkan.

Adapun penjelasan diagram use case rancangan atau desain sistem informasi administrator juga dapat memantau data produk dari sistem pemesanan konsumen.

Tugas marketing (pemasaran) adalah memenuhi kebutuhan dan keinginan

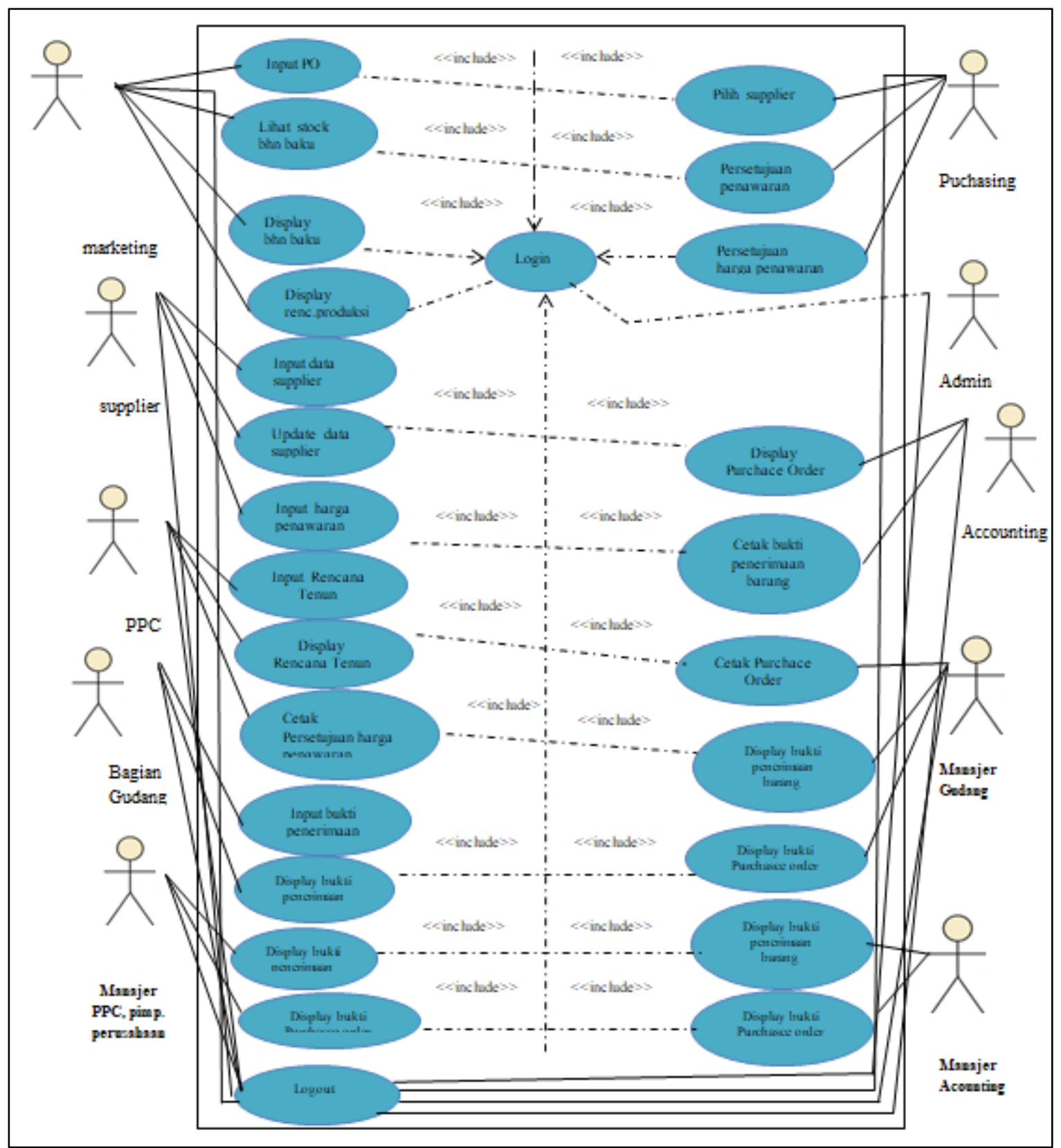

Gambar 3. Use case Usulan Rancangan Sistem Informasi Manajemen Rantai Pasokan

manajemen rantai pasok pada P.T. ABCD dijelaskan berikut ini.

Tugas pokok dari admin (administrator) adalah melakukan penambahan dan mengelola pemakai untuk konsumen, pemasok, distributor dan pengecer. Administrator juga mempunyai tugas dalam tata kelola informasi dan distribusi serta mengelola pesanan konsumenn dan konsumen, melayani konsumen, memasukkan data pemesanan barang (order purchasing) dari konsumen menjalin kerja sama dengan vendor dan agen luar.

Tugas Planning Production Control (PPC) adalah membuat perencanaan produksi, menetapkan dan menyusun urutan produksi, memasukkan data material, mendesain aliran kerja, membuat jadwalan induk produksi, 
mempersiapkan pemesanan produksi, dan waktu penjadwalan produksi.

Tugas Purchase Order (PO) adalah
Tugas manajer accounting adalah menyiapkan laporan harian, mingguan bulanan serta tahunan. Perusahaan, menyiapkan anggaran harian, melakukan

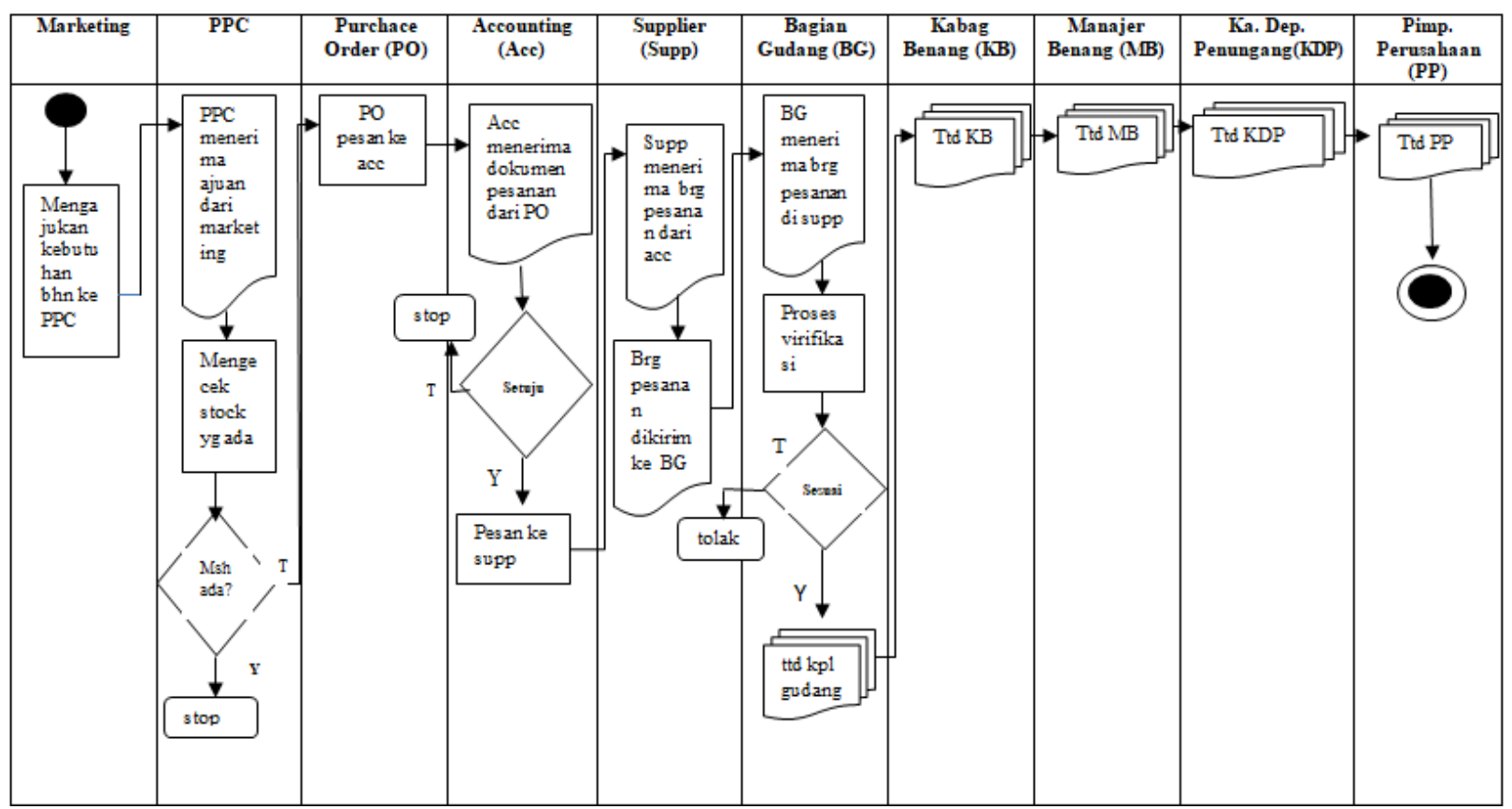

Gambar 4. Diagram activity sistem informasi saai ini yang sedang berjalan pada P.T. ABCD

menyusun daftar perencanaan barang yang ingin dibeli tiap divisi pada perusahaan, membuat dan mengirimkan dokumen pemesanan, quality control terhadap barang yang telah dibeli serta mendokumentasikan dokumen-dokumen pembelian.

Tugas Accounting adalah mengelola dan memproses laporan keuangan dan mencatatnya setiap transaksi, melaksanakan otorisasi pada setiap divisi terkait.

Tugas supplier adalah memberi kepastian tentang ketersediaan bahan baku atau bahan mentah yang dibutukan perusahaan, serta dapat memastikannya keberadaan bahan baku yang supply dalam keadaan baik ketika diterima oleh perusahaan.

Tugas staf gudang atau divisi gudang adalah merencanakan pengadaan barang beserta saluran distribusinya, mengontrol aktivitas operasional gudang, melakukan pemesanan barang sesuai dengan kebutuhan, melakukan pengawasan dan mengontrol masuk dan keluarnya barang yang sesuai dengan standar operasional prosedur (SOP) perusahaan, melakukan chek dan rechek pada barang yang diterima sesuai SOP. validasi transaksi keuangan dan pajak, mengimplementasikan regulasi perpajakan dan keuangan perusahaan dan selalu memantau sistem akuntasi dan perpajakan perusahaan secara berkala.

Tugas manajer PPC adalah mempersiapkan proses produksir dan pengelolaan stok persediaan bahan baku digudang sampai akhirnya diproduksi menjadi barang siap pakai.

Berdasarkan use case yang dibuat pada Gambar 3, dibuatlah activity diagram yang telah dibuat seperti telihat pada Gambar 4.

\section{Kesimpulan}

Berdasarkan hasil dan perancangan sistem informasi manajemen rantai pasokan yang telah dibuat pada P.T. ABCD, maka kesimpulannyaa adalah bahwa sistem informasi manajemen rantai pasokan yang dikembangkan di P.T. ABCD dapat menjadi jalan keluar dalam pemecahan msalah yang dihadapi oleh perusahaan dalam hal ini P.T. $\mathrm{ABCD}$. Beberapa sifat atau karakteristik yang dapat mendukung jalan keluar dari permasalahan tersebut antara lain sebagai berikut: (1) Aplikasi sistem informasi 
manajemen rantai pasok yang dirancang untuk P.T. ABCD dapat mengatasi ketidakpastian rantai pasok pada perusahaan. Sebab, aplikasi sistem tersebut bisa membantu perusahaan dalam pengendalian pengadaan bakan baku yang harus selalu tersedia sesuai dengan kebutuhan perusahaan; (2) Aplikasi sistem informasi manajemen rantai pasok yang dirancang tersebut dapat memantau hubungan antara pemasok dengan perusahaan, perusahaan dengan pemakai yang bisa dengan mudah melakukan pemesanan barang dari pemasok ke perusahaan atau pemesanan barang dari perusahaan ke pelanggan sehingga pendistribusian barang yang dipesan sesuai dengan pesanan dan dapat sampai ke perusahaan dengan tepat waktu; (3) Dapat memberi peluang kepada pemasok (supplier) agar dapat terlibat langsung ke dalam sistem aplikasi tersebut dalam proses permintaan harga barang secara online; (4) Persetujuan pada dokumen pembelian barang dapat dilakukan melalui media online.

\section{Saran-Saran}

Saran-saran atau masukkan yang dapat diberikan peneliti kepada P.T. ABCD adalah sebagai berikut: (1) Agar proses penerapan sistem informasi manajemen rantai pasokan pada P.T. ABCD berjalan lancar, maka harus diberikan pelatihan kepada para pegawai atau karyawan di lingkungan perusahaan P.T. $\mathrm{ABCD}$ tentang cara-cara menggunakan atau mengoperasikan sistem baru tersebut sehingga sistem tersebut dapat berjalan optimal; (2) Untuk peneliti selanjutnya, perlu kiranya dilakukan penelitian untuk mengukur tingkat keefektifan dan keefisienan dari sistem tersebut, baik dari sisi kepuasan para pengguna sistem tersebut maupun dari kemampuan sistem tersebut.

\section{Daftar Referensi}

Agus, A. (2016). Supply Chain Management: The Influence of SCM on Production Performance and Product Quality. Journal of Economics, Business and Management, 3(11), 1046-1053. https://doi.org/10.7763/joebm.2015.v3.3 32

Banerjee, M. (2017). Retail supply chain management practices in India: A business intelligence perspective.
IDEAS, $\quad 34(\mathrm{C}), \quad$ 248-259. https://doi.org/10.1016/j.jretconser.2015. 09.009

Boell, S. K., \& Cecez-Kecmanovic, D. (2015). What is an information system? Proceedings of the Annual Hawaii International Conference on System Sciences, 2015-March(January), 49594968.

https://doi.org/10.1109/HICSS.2015.587

Gholam Ali Ahmadya, Maryam Mehrpour, A. N. (2016). Organizational Structure. Procedia - Social and Behavioral Sciences, 230(May), 455-462. https://doi.org/10.7228/manchester/9780 719070488.003.0003

Jamaludin, M., Hikmat, T., Novan, D., \& Nugraha, S. (2021). Uncertain Supply Chain Management A system dynamics approach for analyzing supply chain industry: Evidence from rice industry. USCM, 9(1). https://doi.org/10.5267/j.uscm.2020.7.00 7

Kowo, S. A., \& Popoola, M. A. (2018). Impact Of External Business Environment On Organizational Performance Sabitu Owotutu Olalekan Ogun state institute of technology igbesa Ogun state. Researchgate.Net, 4(3), 498-505. https://www.researchgate.net/publicatio $\mathrm{n} / 336320140$

Kuznetsova, N. V., Rahimova, L. M., Gafurova, V. M., Simakov, D. B., Zinovyeva, E. G., \& Ivanova, L. A. (2017). External environment as a factor of ensuring the competitiveness of organizations in the regional market of medical services. European Research Studies Journal, 20(4), 308-322.

Magar, D. B., \& Khandare, P. D. M. (2016). Study of Supply Chain Management and Buyer Supplier Relationship. 4(04), 1988-1990.

Meijer, D. K. F. (2013). Information: what do you mean?: on the formative element of our universe. Syntropy, 3, 1-49. http://www.sintropia.it/journal/english/2 013-eng-3-01.pdf

Nafchi, M. Z., \& Mohelská, H. (2020). 
Organizational Culture as an Indication of Readiness. Information, 11(174).

Susanthi, Putu Rani. (2017). Analisis Lingkungan Internal Dan Lingkungan Eksternal Untuk Mencapai Tujuan Perusahaan (Studi Kasus Stie Galileo Batam). Jurnal Elektronik Riset Ekonomi Bidang Manajemen Dan Akuntansi, 1(1), $30-42$.

https://d1wqtxts1xzle7.cloudfront.net/56 283112/Putu-with-cover-pagev2.pdf?Expires $=1626925632 \&$ Signature $=\mathrm{dxnBfuJ} 15 \mathrm{jx} 5 \mathrm{cuS} 2 \mathrm{qGCYtc} 1 \mathrm{HPu} 8 \mathrm{u} 1 \mathrm{df}$ 7iNRtcEi $\sim \mathrm{RC} 3 w \mathrm{KmGiX} \sim \mathrm{WhCzgjE3sha}$ hMutn2HTcFIQgjOAVHI85DrT7Yq U DoYusojd303NmH1XnBwDaQKOppe HtSgEAdWGPyhaQSGJYKep2EsCnC6bkAFI

Rachbini, W. (2016). Supply Chain Management Dan Kinerja Perusahaan. Jurnal Riset Manajemen dan Bisnis, 1(1), 23-30.

file:///C:/Users/maunj/AppData/Local/T emp/7-Article

Text-10-1-1020170415.pdf

Rahmasari, L. (2011). Pengaruh Manajemen Rantai Pasok Terhadap Kinerja perusahaan dan Keunggulan Bersaing (Studi Kasus pada Industri Kreatif di Provinsi Jawa Tengah). Majalah Ilmiah Informatika, 2(3), 89-103. file://C:/Users/maunj/AppData/Local/T emp/49-Article Text-85-1-1020161115.pdf
Ranjith, V. K. (2016). Models of Business and Competitive Advantage. Procedia Economics and Finance, 37(16), 203207. https://doi.org/10.1016/s22125671(16)30114-9

Sadraoui, T., \& Mchirgui, N. (2014). Supply Chain Management Optimization within Information System Development. International Journal of Econometrics and Financial Management, 2(2), 59-71. https://doi.org/10.12691/ijefm-2-2-2

Shu-SanGan, et. all. (2017). Pricing decision for new and remanufactured product in a closed-loop supply chain with separate sales-channel. International Journal of Production Economics, 190(2), 120-132. https://doi.org/10.1016/j.ijpe.2016.08.01 6

Sonata, F.-. (2019). Pemanfaatan UML (Unified Modeling Language) Dalam Perancangan Sistem Informasi ECommerce Jenis Customer-ToCustomer. Jurnal Komunika: Jurnal Komunikasi, Media Dan Informatika, 8(1), 22. https://doi.org/10.31504/komunika.v8i1. 1832

Koech, W., \& Ronoh, R. (2015). Benefits of Supply Chain Management in the Manufacturing Sector. International Journal Of Science And Research, 5(11), 1967-1970. 